\title{
From granuloma to fibrosis in interstitial lung diseases: molecular and cellular interactions
}

\author{
J.F. Mornex, C. Leroux, T. Greenland, D. Ecochard*
}

From granuloma to fibrosis in interstitial lung diseases: molecular and cellular interactions. J.F. Mornex, C. Leroux, T. Greenland, D. Ecochard. CERS Journals Ltd 1994.

ABSTRACT: Granuloma is a feature of many chronic interstitial lung diseases, and may serve as a focus for subsequent fibrosis. Granulomas are composed of structured masses of cells of the macrophage lineage, which adopt an epithelioid aspect, interspersed with lymphocytes. They are formed around local centres of irritation. During their resolution, fibroblasts congregate around the structures and may penetrate the interior.

In many cases, granulomas can disappear without leaving lasting traces. However, especially when damage has occurred to the surrounding tissue, permanent scarring and fibrosis may occur. Both types of cell present in the granuloma are capable of secreting a number of factors influencing the accumulation and proliferation of fibroblasts, both positively and negatively.

The possible roles played by the different factors and, especially, interactions between them are discussed in the light of fibrosis formation. Possible therapeutic interventions are summarized.

Eur Respir J., 1994, 7, 779-785.
Laboratoire d'immunologie et de biologie pulmonaire, INSERM CJF 93-08 and Service de Pneumologie, Hôpital Louis Pradel; Laboratoire de recherche sur les lentivirus des petits ruminants, INRA and Ecole Vétérinaire de Lyon, Lyon, France.

Correspondence: J.F. Mornex

Hôpital Louis Pradel

B.P. Lyon Montchat

69394 Lyon Cedex 03

France

Keywords: Cell communication, cytokines, extrinsic allergic alveolitis, granuloma, sarcoidosis

Received: September 81993

Accepted after revision November 291993

*This work is dedicated to D. Ecochard. $\mathrm{CL}$ is recipient of a Fondation Merieux fellowship.
Several chronic interstitial lung diseases, such as sarcoidosis and hypersensitivity pneumonitis, are characterized by an interstitial cellular infiltrate or alveolitis, granuloma, and varying degrees of interstitial fibrosis [1-3]. Granulomatous lung diseases, like sarcoidosis, hypersensitivity pneumonitis or histiocytosis $\mathrm{X}$, are typified by the formation of granulomas in the alveolar, bronchial and vascular walls [4], although they differ in histological organization. Alveolitis is thought to precede granuloma formation [1, 5]. The subsequent process of fibrosis involves the accumulation of fibroblasts and extracellular matrix around and within the granulomas, and is the main risk for evolution towards permanent pulmonary dysfunction.

Granulomas are structured masses composed of macrophage-derived cells, which assume an epithelioid aspect, and of lymphocytes. They form in response to local irritation, and traces of the irritant material may be recognizable within them [6]. They may occur in any tissue or organ. Their resolution may proceed without alteration of the tissue in which they are embedded, or may involve erosion or replacement by scar tissue. During their resolution, fibroblasts concentrate around the periphery, and may infiltrate the mass. Whether a granuloma progresses to a local or a diffuse fibrotic lesion probably depends on the extent of damage to the surrounding tissue in which the granuloma was embedded.

Over the past years, it has been demonstrated that fibrosis is under the control of inflammatory cells [7], mainly macrophages, and results from interactions between very large numbers of cells; the human lung comprises more than $10^{11}$ alveolar macrophages and interstitial cells [8]. This review focuses on the molecular interactions between inflammatory cells and fibroblasts that lead to fibrosis in granulomatous lung disorders.

\section{Macrophage mediators acting on fibroblasts}

Macrophages are able to release a variety of mediators that can modulate fibroblast functions (table 1). Fibroblast proliferation can be induced by tumor necrosis factoralpha (TNF- $\alpha$ ), transforming growth factor-beta (TGF$\beta$ ), insulin-like growth factor-1 (IGF-1), (previously described as alveolar macrophage-derived growth factor (AMDGF)), interleukin-1-beta (IL-1 $\beta$ ), platelet-derived growth factor (PDGF) and fibronectin [9-12]. Interferongamma (IFN- $\gamma$ ) stimulates proliferation in quiescent fibroblasts but inhibits the multiplication of rapidly dividing cells [11]. Interestingly, TNF- $\alpha$ is able, after intravenous administration, to induce alveolitis and epithelial cell damage in the absence of other factors [13]. TGF- $\beta$ and IGF-1 can induce collagen synthesis [10], while IFN- $\gamma$ [14] and prostaglandin $\mathrm{E}_{2}\left(\mathrm{PGE}_{2}\right)$ [15] downregulate collagen production. TNF- $\alpha$ and IL- $1 \beta$ can induce PGE $_{2}$ secretion [16], while IFN- $\gamma$ decreases it [12]. Finally, the interstitium can be further modified by secreted enzymes, such as collagenase, induced in fibroblasts by TNF- $\alpha$, TGF- $\beta$, IGF- 1 and IL- $1 \beta$ whereas IFN- $\gamma$ and 
Table 1. - Effect of the different macrophage mediators on fibroblast metabolism

\begin{tabular}{lcccc}
\hline & $\begin{array}{c}\text { Cell } \\
\text { proliferation }\end{array}$ & $\begin{array}{c}\text { Collagen } \\
\text { synthesis }\end{array}$ & $\begin{array}{c}\text { PGE } \\
\text { release }\end{array}$ & $\begin{array}{c}\text { Collagenase } \\
\text { secretion }\end{array}$ \\
\hline TNF- $\alpha$ & + & $+/-$ & + & + \\
TGF- $\beta$ & + & + & & + \\
IGF-1/AMDGF & + & + & + & + \\
IL-1 $\beta$ & + & + & & + \\
PDGF & + & + & - & - \\
Fibronectin & +- & - & & \\
IFN- $\gamma$ & & - & & \\
PGE & & & & \\
\hline
\end{tabular}

+: upregulation; -: downregulation; +/-: variable results according to experimental conditions. $\mathrm{PGE}_{2}$ : prostaglandin $\mathrm{E}_{2}$; TNF- $\alpha$ : tumour necrosis factor- $\alpha$; TGF- $\beta$ : transforming growth factor- $\beta$; IGF-1: insulin-like growth factor1; AMDGF: alveolar macrophage-derived growth factor; IL-1 $\beta$ : interleukin-1 $\beta$; PDGF: platelet-derived growth factor; IFN- $\gamma$ : interferon- $\gamma$.

$\mathrm{PGE}_{2}$ decrease its secretion [10]. Alveolar macrophages are also able to modulate the proliferation of type II pneumocytes [17].

Increased release of macrophage mediators in granulomatous lung disorders

The above mediators have been shown to be released by macrophages in most spontaneous [10, 18] and experimental [19] granulomatous lung disorders (table 2). For instance, an increased spontaneous secretion of TNF- $\alpha$ by alveolar macrophages is observed in hypersensitivity pneumonitis [20] and in sarcoidosis [21-24], although in this disease other investigators only observed increased levels of TNF- $\alpha$ after induction by lipopolysaccharide (LPS) [25, 26]. These discrepancies are more likely to be due to differences in patient populations than to technical aspects of the assay. Increased macrophage expression of the TNF- $\alpha$ gene has been reported in chronic beryllium disease [27], and in an experimental model of granulomatous lung disease, where the release of TNF$\alpha$ by alveolar macrophages is increased in mice 4 weeks after intranasal instillation of Faeni rectivirgula [28].

IGF-1 (previously AMDGF) is also released in excess by alveolar macrophages in sarcoidosis, hypersensitivity pneumonitis, histiocytosis $X$ and berylliosis [29], as is fibronectin [30]. The level of PDGF gene expression is increased in histiocytosis $\mathrm{X}$ [31]. As far as IL-1 is concerned, the data are less clear. Whilst there is an increased spontaneous release of IL-1 by alveolar macrophages 2 weeks after intranasal instillation of Faeni rectivirgula in mice [28], and in hypersensitivity pneu- monitis in human [20], the release of IL-1 has been a matter of controversy in sarcoidosis. It is known that the epithelioid granuloma cells and alveolar macrophages express cytoplasmic IL-1 [32], and that, in experimental pulmonary granulomatous disorders, both giant cells [4] and epithelioid cells produce IL-1 [33]. The spontaneous [34] or LPS-induced [35] release of IL-1 by alveolar macrophages in sarcoidosis was initially thought to be increased. But the levels of IL-1 $\beta$ messenger ribonucleic acid (mRNA) is not increased in the alveolar macrophages in sarcoidosis patients when compared to controls [36], in keeping with data showing that alveolar macrophages per se express the IL-1 gene poorly [37].

Macrophage adhesion and activation are early events, as shown in vitro [38] and in vivo [39] after Schistosoma mansoni infection, during leprosy [40], in tuberculosis $[41,42]$, and after visna maedi virus infection in sheep [43, 44].

Considering only the fibrosis-inducing mediators released by alveolar macrophages, it is clear that most of them are spontaneously released in excess in granulomatous lung diseases (table 2). Similarly, the cytokine gene expression in leprosy granulomas shows increased levels of IL-1, TGF- $\beta$ and granulocyte macrophage colony stimulating factor (GM-CSF) mRNAs [45].

\section{Interaction with lymphocytes and expansion of mononuclear phagocytes}

The degree of structural formation of granulomas varies in different conditions, reflecting a difference in the organizing activity of the cells involved. Cellular adhesion

Table 2. - Increased release of the different macrophage mediators acting on fibroblast metabolism associated with granulomatous lung disorders

\begin{tabular}{|c|c|c|c|c|c|c|}
\hline & TNF- $\alpha$ & IGF-1 & IL-1 $\beta$ & PDGF & Fn & IFN- $\gamma$ \\
\hline Sarcoidosis & + & + & + & & + & + \\
\hline Hypersensitivity pneumonitis & + & + & & & + & \\
\hline Experimental HP & + & & + & & & \\
\hline Histiocytosis $\mathrm{X}$ & & + & & + & + & \\
\hline Berylliosis & + & + & & & + & \\
\hline
\end{tabular}

Fn: fibronectin; HP: hypersensitivity pneumonitis. For further abbreviations see legend to table 1 . 
molecules participate in the localization of macrophages and in antigen presentation by them [46], and increased expression of CD11b and CD54 by alveolar macrophages has been observed in sarcoidosis [46, 47], and hypersensitivity pneumonitis [48]. Another potential mediator is basic fibroblast growth factor (bFGF), which is known to modify cell adhesion properties [49], and is produced by macrophages.

These molecules play a crucial role in the structural formation of tissues, and the level of their expression is a probable factor in the organization of a granuloma [6], and hence the type of fibrotic lesion which may follow its unsatisfactory resolution. The level of vitronectin, a mediator involved in cell adhesion, in bronchoalveolar lavage is consistently elevated in sarcoidosis [50], and in hypersensitivity pneumonitis [51]. The number of macrophages may also be increased by local proliferation within the alveolar spaces [52], and in the granulomas [32].

\section{Modifications of fibroblast metabolism}

Modifications of fibroblast metabolism, probably due to the action of these mediators, have been observed in most of these disorders. Fibroblast activation is strongly suggested by the presence in bronchoalveolar lavage of an increased level of procollagen III terminal peptide in sarcoidosis [53], and in hypersensitivity pneumonitis $[54,55]$, and of hyaluronic acid both in sarcoidosis [56, 57], and symptomatic hypersensitivity pneumonitis [54]. Thus, most interstitial lung diseases with granuloma formation are characterized by an increased spontaneous release by alveolar macrophages of cytokines able to stimulate fibroblast metabolism, and indeed, increased fibroblast metabolism can be demonstrated in most of these natural disorders. Increased lung collagen is also observed in experimental hypersensitivity pneumonitis [58].

\section{Role of lymphocytes}

Lymphocytes are able to modulate fibroblast function $[59,60]$, but whilst they stimulate proliferation in idiopathic pulmonary fibrosis, they have a negative effect in hypersensitivity pneumonitis [61]. They can modulate the influx of monocytes to the alveolar spaces and granulomas, in concert with immature monocyte-like macrophages, as shown in sarcoidosis by phenotype [62], and function [63]. Finally, CD4 positive T-cells accumulate during granuloma formation in tuberculosis [64], and sarcoidosis [65].

\section{Differences in the pattern of fibrosis}

The pattern of fibrosis clearly differs between the various granulomatous diseases. They can be associated either with a diffuse interstitial lung fibrosis, as in the case of hypersensitivity pneumonitis, or a focal perigranulomatous fibrosis as in sarcoidosis.

The cells constituting a granuloma can and do secrete factors that attract and stimulate fibroblasts. They can also secrete factors which limit fibroblast activity and which reabsorb the collagen produced. Not all granulomas lead to fibrosis, and not all fibrosis is preceded by a granuloma. Macrophages and T-lymphocytes can secrete fibroblast-modifying factors in contexts other than granulomas. Diffuse fibrosis could result from the expression of the same activities by cells which have not organized into a granulomatous structure. The precipitating factor may be diffusely present in the organ, or the responding cells may not be induced to organize, or may respond differently to stimulatory mediators $[66,67]$. Multiple factors are probably involved in these differences in the fibrotic process:

1) The level of release of mediators by alveolar macrophages may differ. For example, the level of release of both IGF-1 [29], and fibronectin [30], is lower in sarcoidosis than in idiopathic pulmonary fibrosis. Similarly, the level of expression of PDGF $\beta$ by alveolar macrophages is lower in sarcoidosis than in idiopathic pulmonary fibrosis [68].

2) Inhibitory mediators can be released, for instance, IFN$\gamma$ released during sarcoidosis can down-regulate the activation of fibroblasts [69, 70], and, indeed, changes in fibrin structure, indicated by increased levels of D dimer in bronchoalveolar fluid, suggest a diminution of fibrinogenesis in sarcoidosis [71].

3) The mediators can interact. Both IL- $1 \beta$ or TNF- $\alpha$ stimulate the proliferation of fibroblasts; however, when added together to cell cultures they inhibit this proliferation [72]. IL- $1 \beta$ potentiates, but $\mathrm{PGE}_{2}$ blocks the proliferation induced by the association of fibronectin and IGF-1 [73]. TNF- $\alpha$ and IFN- $\gamma$ added together block the stimulatory effect of TGF- $\beta$ on collagen production [74]. Some mechanisms underlying these interactions have been proposed: for example, PDGF induces IL-1 receptors on fibroblasts [75], and IL-1 induces the expression of PDGF [76]. It should, however, be noted that all the preceding tests have been performed in vitro, and the results of similar associations in vivo are unknown.

4) Fibroblasts can modulate other cell types. There are clear interactions between macrophages and fibroblasts. Fibroblasts can release mediators, including cytokines, that can in turn act on macrophages and other fibroblasts. TNF- $\alpha$ and IL-1 $\beta$ [16], or PDGF [4], can induce fibroblasts to release $\mathrm{PGE}_{2}$, which inhibits macrophages and fibroblasts. In vitro, fibroblasts stimulated by TNF- $\alpha$ expressed monocyte chemoattractant protein-1 (MCP-1-huJE), able to attract and activate monocytes) [77], and macrophage inflammatory protein-2 (MIP-2), a proinflammatory cytokine [78]. In vivo, lung cells expressed high levels of mRNA for MCP-1-huJE in experimental pulmonary granulomatosis [79], and of mRNA for MIP-1 $\alpha$ and MIP-2 after experimental exposure to silica [78].

5) Interactions with the extracellular matrix occur and play a role in controlling these interactions. Extracellular matrix can locally concentrate cytokines, such as TGF$\beta$ and PDGF. Collagen and collagen fragments stimulate alveolar macrophages to release IL-1 $\beta$, IL-6 [80], and neutrophil chemotactic activity [81]. Additionally, complex structures, such as acellular sarcoid granulomas, can directly activate fibroblasts to release collagenase and stromelysin [82]. 
Table 3. - Inhibitory effect of therapeutic agents on the production of macrophage mediators

\begin{tabular}{lcccc}
\hline & $\begin{array}{c}\text { Corticoids } \\
\text { in vitro }\end{array}$ & $\begin{array}{c}\text { Corticoids } \\
\text { in vivo }\end{array}$ & $\begin{array}{c}\text { Colchicine } \\
\text { in vitro }\end{array}$ & $\begin{array}{c}\text { Methotrexate } \\
\text { in vivo }\end{array}$ \\
\hline TNF- $\alpha$ & + & + & & + \\
IGF-1/AMDGF & - & - & + & \\
IL-1 $\beta$ & + & + & + & \\
Fibronectin & - & - & + & \\
\hline
\end{tabular}

+: inhibitory effect; -: lack of inhibitory effect. For abbreviations see legend to table 1.

6) Finally, damage to the alveolar epithelium seems necessary for the induction of fibrosis [83], and differs between the various disorders. It has been clearly demonstrated that epithelial cell damage leaves the epithelial basement membranes denuded and favours disruption. Inflammatory and interstitial cells can then enter the alveolar spaces, initiating intra-alveolar fibrosis, and leading to alveolar collapse and/or coalescence and intramural incorporation of the intra-alveolar fibrosis. This sequence of events has been shown by analysis of the pathology in hypersensitivity pneumonitis [84-86], and histiocytosis $X$ [87]. In contrast, less epithelial cell damage is observed in sarcoidosis [88]. Damage to the epithelial cells can be monitored by measuring the serum level of an antigen (KL-6), expressed on type II pneumocytes and bronchiolar epithelial cells, which is increased in the serum of patients with idiopathic pulmonary fibrosis and hypersensitivity pneumonitis, but not sarcoidosis [89].

\section{Therapeutic implications}

Our understanding of the role of these mediators may have therapeutic implications (table 3). Several agents have a potential for modifying the production or release of important factors. Whilst corticosteroids do not inhibit the release of IGF-1 or fibronectin by macrophages either in vitro or in vivo [90], colchicine is able to inhibit both secretions in vitro [91]. Corticosteroids can, however, block the release of TNF- $\alpha$ by alveolar macrophages in vitro [92], and in vivo [20, 21], and of IL-1 both in vitro [35], and in vivo [20]. Finally, TNF- $\alpha$ release is inhibited by methotrexate [21]. Anti-TNF- $\alpha$ is able to decrease the fibrosis observed in mice after intranasal instillation of Faeni rectivirgula [28], showing the potential for clinical improvement by interference with the mediators of the fibrosis process.

In conclusion, pulmonary fibrosis is modulated by inflammatory cells, mainly macrophages, in the alveolar spaces and in the granuloma itself. Additional factors (e.g. balance of mediators, interactions with the extracellular matrix) play a role. Suppression of cytokine production and/or effect is a method of interfering with the induction of fibrosis.

\section{References}

1. Keogh BA, Crystal RG. Alveolitis: the key to the interstitial lung disorders. Thorax 1982; 37: 1-10.
2. Reyes CN, Wenzel FJ, Lawton BR, Emanuel DA. The pulmonary pathology of farmer's lung disease. Chest 1982; 81: 142-146.

3. Costabel U. The alveolitis of hypersensitivity pneumonitis. Eur Respir J 1988; 1: 5-9.

4. Kunkel SL, Chensue SW, Strieter RM, Lynch JP, Remick DG. Cellular and molecular aspects of granulomatous inflammation. Am J Respir Cell Mol Biol 1989; 1: 439-447.

5. Chang JC, Jagirdar J, Lesser M. Long-term evolution of BCG- and CFA-induced granulomas in rat lungs. Correlation of histologic features with cells in bronchoalveolar lavage samples. Am J Pathol 1986; 125: 16-27.

6. Kunkel SL, Strieter RM, Lukacs N, Chensue SW. Initiation and maintenance of granulomatous response. Chest 1993; 103: 135S-137S.

7. Crystal RG, Bitterman PB, Rennard SI, Keogh BA. Interstitial lung disease of unknown etiology: disorders characterized by chronic inflammation of the lower respiratory tract. N Engl J Med 1984; 310: 154-166.

8. Crapo JD, Barry BE, Gehr P, Bachofen M, Weibel ER. Cell number and cell characteristics of the normal human lung. Am Rev Respir Dis 1982; 125: 332-337.

9. Rom WN, Basset P, Fells GA, Nukiwa T, Trapnell BC, Crystal RG. Alveolar macrophages release an insulinlike growth factor-1 type molecule. J Clin Invest 1988; 82: 1685-1693.

10. Kelley J. Cytokines of the lung. Am Rev Respir Dis 1990; 141: 765-788.

11. Elias JA, Kotloff R. Mononuclear cell-fibroblast interactions in the human lung. Chest 1991; 99: 73S-78S.

12. Kovacs E. Fibrogenic cytokines: the role of immune mediators in the development of scar tissue. Immunol Today 1991; 12: 17-23.

13. Johnson J, Brigham KL, Jesmok G, Meyrick B. Morphologic changes in lungs of anesthetized sheep following intravenous infusion of recombinant tumor necrosis factor$\alpha$. Am Rev Respir Dis 1991; 144: 179-186.

14. Narayanan AS, Whithey J, Souza A, Raghu G. Effect of $\gamma$-interferon on collagen synthesis by normal and fibrotic human lung fibroblasts. Chest 1992; 101: 13261331.

15. Goldstein RH. Control of type I collagen formation in the lung. Am J Physiol 1991; 261: L29-L40.

16. Elias JA, Gustilo K, Baeder W, Freundlich B. Synergistic stimulation of fibroblast prostaglandin production by recombinant interleukin-1 and tumor necrosis factor. J Immunol 1987; 138: 3812-3816.

17. Brandes ME, Finkelstein JN. Stimulated rabbit alveolar macrophages secrete a growth factor for type II pneumocytes. Am J Respir Cell Mol Biol 1989; 1: 101-109.

18. Carré $\mathrm{P}$, Léophonte P. Cytokines et fibroses pulmonaires. Rev Mal Respir 1993; 10: 193-207.

19. Mornex JF. Modèles expérimentaux de pneumopathies interstitielles. Encycl Med Chir Pneumologie 1991; 6039E20: 1-12. 
20. Denis M, Bedard M, Laviolette M, Cormier Y. A study of monokine release and natural killer activity in the bronchoalveolar lavage of subjects with farmer's lung. Am Rev Respir Dis 1993; 147: 934-939.

21. Baughman RP, Lower EE. The effect of corticosteroid or methotrexate therapy on lung lymphocytes and macrophages in sarcoidosis. Am Rev Respir Dis 1990; 142: $1268-1271$.

22. Foley NM, Millar AB, Johnson NM, Rook GAW. Tumour necrosis factor production by alveolar macrophages in pulmonary sarcoidosis and tuberculosis. Sarcoidosis 1992; 9: 29-34.

23. Müller-Quernheim J, Pfeifer S, Männel D, Strausz J, Ferlinz R. Lung-restricted activation of the alveolar macrophage/monocyte system in pulmonary sarcoidosis. Am Rev Respir Dis 1992; 145: 187-192.

24. Homolka J, Müller-Quernheim J. Increased interleukin6 production by bronchoalveolar lavage cells in patients with active sarcoidosis. Lung 1993; 171: 173-183.

25. Bachwich PR, Lynch JP, Larrick J, Spengler M, Kunkel SL. Tumor necrosis factor production by human sarcoid alveolar macrophages. Am J Pathol 1986; 125: 421-425.

26. Spatafora M, Merendino A, Chiappara G, Gjomarkaj M, Bonsignore $\mathrm{G}$. Lung compartmentalization of increased TNF releasing ability by mononuclear phagocytes in pulmonary sarcoidosis. Chest 1989; 96: 542-549.

27. Bost T, Newman L, Riches D. Increased TNF- $\alpha$ and IL-6 mRNA expression by alveolar macrophages in chronic beryllium disease. Chest 1993; 103: 138S.

28. Denis M, Cormier Y, Laviolette M. Murine hypersensitivity pneumonitis: a study of cellular infiltrates and cytokine production and its modulation by cyclosporin A. Am J Respir Cell Mol Biol 1992; 6: 68-74.

29. Bitterman PB, Adelberg S, Crystal RG. Mechanisms of pulmonary fibrosis. Spontaneous release of the alveolar macrophage-derived growth factor in the interstitial lung disorders. J Clin Invest 1983; 72: 1801-1813.

30. Rennard SI, Hunninghake GW, Bitterman PB, Crystal RG. Production of fibronectin by the human alveolar macrophages: mechanism for the recruitment of fibroblast to sites of tissue injury in interstitial lung disease. Proc Natl Acad Sci USA 1981; 78: 7147-7151.

31. Barth J, Radzun HJ, Petermann W, Bewing B, Parwaresch MR. Increased expression of growth factor genes for macrophages and fibroblasts in bronchoalveolar lavage cells of a patient with pulmonary histiocytosis X. Thorax 1991; 46: 835-838.

32. Chilosi M, Menestrina F, Capelli P, et al. Immunohistochemical analysis of sarcoid granulomas. Evaluation of Ki67+ and interleukin-1+ cells. Am J Pathol 1988; 131: 191-198.

33. Abe $\mathrm{Y}$, Tsuda $\mathrm{T}$, Okajima $\mathrm{T}$. In vitro angiotensinconverting enzymes and interleukin-1 production by epithelioid cells isolated from induced rabbit lung granuloma. Exp Lung Res 1990; 16: 489-505.

34. Hunninghake GW. Release of interleukin-1 by alveolar macrophages of patients with active pulmonary sarcoidosis. Am Rev Respir Dis 1984; 129: 569-572.

35. Nagai S, Aung H, Takeuchi M, Kusume K, Izumi T. IL1 and IL-1 inhibitory activity in the culture supernatants of alveolar macrophages from patients with interstitial lung diseases. Chest 1991; 99: 674-680.

36. Kern JA, Lamb RJ. Interleukin-1-beta gene expression in human monocytes and alveolar macrophages from normal subjects and patients with sarcoidosis. Am Rev Respir Dis 1988; 137: 1180-1184.

37. Wewers MD, Rennard SI, Hance AJ, Bitterman PB,
Crystal RG. Normal human alveolar macrophages obtained by bronchoalveolar lavage have a limited capacity to release interleukin-1. J Clin Invest 1984; 74: 22082218.

38. Doughty BL, Phillips SM. Delayed hypersensitivity granuloma formation around Schistosoma mansoni eggs in vitro. J Immunol 1982; 128: 30-42.

39. Stadecker MJ, Wyler DJ, Wright JA. Ia antigen expression and antigen-presenting function by macrophages isolated from hypersensitivity granulomas. J Immunol 1982; 128: 2739-2744.

40. Van Voorhis WC, Kaplan G, Nunes Sarno E, et al. The cutaneous infiltrate of leprosy. Cellular characteristics and the predominant T-cell phenotypes. N Engl J Med 1982; 307: 1593-1597.

41. Dannenberg AM. Immune mechanisms in the pathogenesis of pulmonary tuberculosis. Rev Infect Dis 1989; 11: S369-S378.

42. Dannenberg AM. Delayed-type hypersensitivity and cellmediated immunity in the pathogenesis of tuberculosis. Immunol Today 1991; 12: 228-233.

43. Cordier $\mathrm{G}$, Cozon $\mathrm{G}$, Greenland $\mathrm{T}$, et al. In vivo activation of alveolar macrophages in ovine lentivirus infection. Clin Immunol Immunopathol 1990; 55: 355-367.

44. Cordier G, Guiguen F, Cadoré JL, Cozon G, Jacquier MF, Mornex JF. Characterization of the lymphocytic alveolitis in visna maedi virus-induced interstitial lung disease of sheep. Clin Exp Immunol 1992; 90: 18-24.

45. Yamamora M, Uyemura K, Deans RJ, et al. Defining protective responses to pathogens: cytokine profiles in leprosy lesion. Science 1991; 254: 277-279.

46. Striz I, Wang YM, Kalaycioglu O, Costabel U. Expression of alveolar macrophage adhesion molecules in pulmonary sarcoidosis. Chest 1992; 102: 882-886.

47. Spiteri MA, Clarke SW, Poulter LW. Alveolar macrophages that suppress T-cell responses may be crucial to the pathogenetic outcome of pulmonary sarcoidosis. Eur Respir J 1992; 5: 394-403.

48. Hoogsteden HC, Van Hal PT, Wijkhuijs JM, Hop W, Hilvering C. Expression of the CD11/CD18 cell surface adhesion glycoprotein family and MHC class II antigen on blood monocytes and alveolar macrophages in interstitial lung diseases. Lung 1992; 170: 221-233.

49. Schubert D, Ling N, Baird A. Multiple influences of a heparin-binding growth factor on neuronal development. J Cell Biol 1987; 104: 635-643.

50. Pohl W, Thompson A, Köhn H, et al. Serum procollagen III peptide levels in subjects with sarcoidosis. A 5 year follow-up study. Am Rev Respir Dis 1992; 145: 412-417.

51. Teschler H, Pohl WR, Thompson AB, et al. Elevated levels of bronchoalveolar lavage vitronectin in hypersensitivity pneumonitis. Am Rev Respir Dis 1993; 147: 332-337.

52. Bitterman PB, Saltzman LE, Adelberg S, Ferrans VJ, Crystal RG. Alveolar macrophage replication: one mechanism for the expansion of mononuclear phagocyte population in the chronically inflamed lung. J Clin Invest 1984; 74: 460-469.

53. Low RB, Cutroneo KR, Davis GS, Giancola MS. Lavage type III procollagen $\mathrm{N}$-terminal peptides in human pulmonary fibrosis and sarcoidosis. Lab Invest 1983; 48: 755-759.

54. Larsson K, Eklund A, Malmberg P, Bjermer L, Lundgren $\mathrm{R}$, Belin L. Hyaluronic acid (hyaluronan) in BAL fluid distinguishes farmers with allergic alveolitis from farmers with asymptomatic alveolitis. Chest 1992; 101: 109_ 114. 
55. Teschler H, Thompson AB, Pohl WR, Konietzko N, Rennard SI, Costabel U. Bronchoalveolar lavage procollagen-III peptide in recent onset hypersensitivity pneumonitis: correlation with the extracellular matrix components. Eur Respir J 1993; 6: 709-714.

56. Hällgren R, Eklund A, Engström-Laurent A, Schmeker B. Hyaluronate in bronchoalveolar lavage fluid: a new marker in sarcoidosis reflecting pulmonary disease. $\mathrm{Br}$ Med J 1985; 290: 1778-1781.

57. Bjermer L, Eklund A, Blaschke E. Bronchoalveolar lavage fibronectin in patients with sarcoidosis: correlation to hyaluronan and disease activity. Eur Respir J 1991; 4: 965-971.

58. Fulmer JD, Flint A, Law DE. Experimental granulomatous lung disease in guinea-pigs. Morphology and collagen analysis. Lung 1983; 161: 337-348.

59. Saita N, Ando M, Araki S, Yoshinaga M. Fibroblasts proliferation factors in pulmonary granuloma induced by Trichosporon cutaneum in rabbits: presence of a lymphocytederived fibroblast proliferation factor and its functional specificity. Int Arch Allergy Appl Immunol 1991; 95: 294-302.

60. Prakash S, Wyler DJ. Fibroblast stimulation in schistosomiasis. XII. Identification of CD4+ lymphocytes within schistosomal egg granulomas as a source of an apparently novel fibroblast growth factor (FsF-1). $J$ Immunol 1992; 148: 3583-3587.

61. Selman M, Gonzalez G, Bravo M, et al. Effect of lung T-lymphocytes on fibroblasts in idiopathic pulmonary fibrosis and extrinsic allergic alveolitis. Thorax 1990; 45: 451-455.

62. Hance AJ, Douches S, Winchester RJ, Ferrans VJ, Crystal RG. Characterization of mononuclear phagocyte subpopulations in the human lung by using monoclonal antibodies: changes in alveolar macrophage phenotype associated with pulmonary sarcoidosis. J Immunol 1985; 134 : 284-292.

63. Semenzato G. Immunology of interstitial lung diseases: cellular events taking place in the lung of sarcoidosis, hypersensitivity pneumonitis and HIV infection. Eur Respir J 1991; 4: 94-102.

64. Randhawa PS. Lymphocyte subsets in granulomas of human tuberculosis: an in situ immunofluorescence study using monoclonal antibodies. Pathology 1990; 22: 153-155.

65. Semenzato G, Pezzutto A, Pizzolo G, et al. Immunohistological study in sarcoidosis: evaluation at different sites of disease activity. Clin Immunol Immunopathol 1984; 30: 29-40.

66. Mio T, Nagai S, Kitaicji M, Kawatani A, Izumi T. Proliferative characteristics of fibroblast lines derived from open lung biopsy specimens of patients with IPF (UIP). Chest 1992; 102: 832-837.

67. Pardo A, Selman M, Ramirez R, et al. Production of collagenase and tissue inhibitor of metalloproteinases by fibroblasts derived from normal and fibrotic human lungs. Chest 1992; 102: 1085-1089.

68. Mornex JF, Martinet Y, Yamauchi K, et al. Spontaneous expression of the c-sis gene and release of a plateletderived growth factor-like molecule by human alveolar macrophages. J Clin Invest 1986; 78: 61-66.

69. Robinson BWS, McLemore TL, Crystal RG. Gammainterferon is spontaneously released by alveolar macrophages and lung T-lymphocytes in patients with pulmonary sarcoidosis. J Clin Invest 1985; 75: 1488-1495.

70. Moseley PL, Hemken C, Monick M, Nugent K, Hunninghake GW. Interferon and growth factor activity for human lung fibroblasts. Release from bronchoalveolar cells from patients with active sarcoidosis. Chest 1986; 89: 657-662.

71. Perez RL, Duncan A, Hunter RL, Staton JW. Elevated D dimer in the lungs and blood of patients with sarcoidosis. Chest 1993; 103: 1100-1106.

72. Elias JA, Gustilo K, Freundlich B. Human alveolar macrophage and blood monocyte inhibition of fibroblast proliferation. Evidence for synergy between interleukin1 and tumor necrosis factor. Am Rev Respir Dis 1988; 138: 1595-1603.

73. Bitterman PB, Wewers MD, Rennard SI, Adelberg S, Crystal RG. Modulation of alveolar macrophage-driven fibroblast proliferation by alternative macrophage mediators. J Clin Invest 1986; 77: 700-708.

74. Kähäri V, Qui Chen Y, Wan Su M, Ramirez F, Uitto J. Tumor necrosis factor- $\alpha$ and interferon- $\gamma$ suppress the activation of human type-1 collagen gene expression by transforming growth factor- $1 \beta$. Evidence for two distinct mechanisms of inhibition at the transcriptional and posttranscriptional levels. J Clin Invest 1990; 86: 1489-1495.

75. Bonin PD, Singh JP. Modulation of interleukin-1 receptor expression and interleukin-1 response in fibroblast by platelet-derived growth factor. J Biol Chem 1988; 263: 11052-11055.

76. Raines EW, Dower SK, Ross R. Interleukin-1 mitogenic activity for fibroblasts and smooth muscle cells is due to PDGF-AA. Science 1989; 243: 393-396.

77. Standiford TJ, Rolfe MR, Kunkel SL, et al. Altered production and regulation of monocyte chemoattractant protein-1 from pulmonary fibroblasts isolated from patients with idiopathic pulmonary fibrosis. Chest 1993; 103: 121S.

78. Driscoll KE, Hassenbein DG, Carter J, et al. Macrophage inflammatory proteins 1 and 2: expression by rat alveolar macrophages, fibroblasts and epithelial cells, and in rat lung after dust exposure. Am J Respir Cell Mol Biol 1993; 8: 311-318.

79. Jones ML, Warren JS. Monocyte chemoattractant protein1 in a rat model of pulmonary granulomatosis. Lab Invest 1992; 66: 498-503.

80. Xing Z, Jordana M, Gauldie J. IL-1 $\beta$ and IL-6 gene expression in alveolar macrophages: modulation by extracellular matrices. Am J Physiol 1992; 262: L600-L605.

81. Laskin DL, Soltys RA, Berg RA, Riley DJ. Activation of neutrophils by factors released from alveolar macrophages stimulated with collagen-like polypeptides. Am J Respir Cell Mol Biol 1990; 2: 463-470.

82. Emonard H, Takiya C, Dreze S, Cordier JF, Grimaux JA. Interstitial collagenase (MMP-1), gelatinase (MMP2) and stromelysin (MMP-3) released by human fibroblasts cultured on acellular sarcoid granulomas (sarcoid matrix complex, SMC). Matrix 1989; 9: 382-388.

83. Rennard SI, Bitterman PB, Crystal RG. Response of the lower respiratory tract to injury. Mechanisms of repair of the parenchymal cells of the alveolar wall. Chest 1983; 84: 735-739.

84. Kawanami O, Basset F, Barrios R, Lacronique JG, Ferrans VG, Crystal RG. Hypersensitivity pneumonitis in man. Light and electron microscopic studies of 18 lung biopsies. Am J Pathol 1983; 110: 275-289.

85. Quezada AL, Gimpel SF, Miranda DO, Las Heras JB, Andreis MC. Ultrastructural features of alveolar cells in experimental hypersensitivity pneumonitis. Respiration 1987; 51: 127-136.

86. Basset F, Ferrans VJ, Soler P, Takemura T, Fukuda Y, 
Crystal RG. Intraluminal fibrosis in interstitial lung disorders. Am J Pathol 1986; 122: 443-461.

87. Fukuda Y, Basset F, Soler P, Ferrans VJ, Masugi Y, Crystal RG. Intraluminal fibrosis and elastic fiber degradation lead to lung remodeling in pulmonary Langerhans' cell granulomatosis (histiocytosis X). Am J Pathol 1990; 137: 415-424.

88. Kawanami O, Ferrans VJ, Crystal RG. Structure of alveolar epithelial cells in patients with fibrotic lung disorders. Lab Invest 1982; 46: 39-53.

89. Khono N, Kyoizumi S, Awaya Y, Fukuhara H, Yamakido M, Akiyama M. New serum indicator of interstitial pneumonitis activity. Sialylated carbohydrate antigen KL-6. Chest 1989; 96: 68-73.

90. Lacronique JG, Rennard SI, Bitterman PB, Ozaki T,
Crystal RG. Alveolar macrophages in idiopathic pulmonary fibrosis have glucocorticoid receptors, but glucocorticoid therapy does not suppress alveolar macrophage release of fibronectin and alveolar macrophage-derived growth factor. Am Rev Respir Dis 1984; 130: 450-456.

91. Rennard SI, Bitterman PB, Ozaki T, Rom WN, Crystal RG. Colchicine suppresses the release of fibroblast growth factors from alveolar macrophages in vitro. The basis of a possible therapeutic approach to the fibrotic disorders. Am Rev Respir Dis 1988; 137: 181185.

92. Martinet N, Vaillant P, Charles T, Lambert J, Martinet Y. Dexamethasone modulation of tumour necrosis factor$\alpha$ (cachectin) release by activated normal human alveolar macrophages. Eur Respir J 1992; 5: 67-72. 